\title{
Rhizobium etli bv. mimosae, a novel biovar isolated from Mimosa affinis
}

\author{
En Tao Wang, M. Antonio Rogel, Alejandro García-de los Santos, \\ Julio Martínez-Romero, Miguel A. Cevallos \\ and Esperanza Martínez-Romero
}

Centro de Investigación sobre Fijación de Nitrógeno, Universidad Nacional Autónoma de México, Ap. P. 565-A, Cuernavaca, Morelos, Mexico
Author for correspondence: Esperanza Martínez-Romero. Tel: +5273131697. Fax: +5273175581. e-mail: emartine@cifn.unam.mx

\begin{abstract}
Fifty rhizobial isolates from root nodules of Mimosa affinis, a small leguminous plant native to Mexico, were identified as Rhizobium etli on the basis of the results of PCR-RFLP and RFLP analyses of small-subunit rRNA genes, multilocus enzyme electrophoresis and DNA-DNA homology. They are, however, a restricted group of lineages with low genetic diversity within the species. The isolates from $M$. affinis differed from the $R$. etli strains that originated from bean plants (Phaseolus vulgaris) in the size and replicator region of the symbiotic plasmid and in symbiotic-plasmid-borne traits such as nifH gene sequence and organization, melanin production and host specificity. A new biovar, bv. mimosae, is proposed within $R$. etli to encompass Rhizobium isolates obtained from $M$. affinis. The strains from common bean plants have been designated previously as $R$. etli bv. phaseoli. Strains of both $R$. et $l i$ biovars could nodulate $P$. vulgaris, but only those of bv. mimosae could form nitrogen-fixing nodules on Leucaena leucocephala.
\end{abstract}

Keywords: Rhizobium etli, Mimosa affinis, symbiotic plasmid, genetic diversity

\section{INTRODUCTION}

The Leguminosae is one of the largest families of plants. A remarkable characteristic of many species in this family is that they establish symbioses with nitrogen-fixing bacteria. In comparison with the large number of leguminous species, there is a very limited number of species within the genera Rhizobium, Sinorhizobium, Bradyrhizobium, Azorhizobium (for reviews see Martínez-Romero \& Caballero-Mellado, 1996; Young \& Haukka, 1996) and the newly proposed Mesorhizobium (Jarvis et al., 1997) and Allorhizobium (de Lajudie et al., 1998b) that form nodules on the roots and sometimes on the stems of legumes. Species such as Rhizobium galegae (Lindström, 1989), Rhizobium huautlense (Wang et al., 1998), Rhizobium mongolense (van Berkum et al., 1998), Rhizobium hainanense (Chen et al., 1997), Mesorhizobium huakuii (Chen et al., 1991), Mesorhizobium ciceri (Nour et al., 1994), Mesorhizobium mediterraneum (Nour et al.,

Abbreviations: ET, electrophoretic type; MLEE, multilocus enzyme electrophoresis; SSU, small-subunit.

The GenBank accession number for the nifH gene sequence of isolate Mim2 is AF107621.
1995), Mesorhizobium tianshanense (Chen et al., 1995; Tan et al., 1997) and Azorhizobium caulinodans (Dreyfus et al., 1988) have been proposed from the study of novel isolates obtained from leguminous plants that had not been previously analysed.

The family Leguminosae is considered to be of tropical or subtropical origin (Raven \& Polhill, 1981). Many tropical species are virtually unknown elsewhere. In a survey of legume-nodule bacteria based on smallsubunit (SSU) rRNA gene sequences, most of the Rhizobium and Bradyrhizobium strains belonging to new varieties were isolated from the tropics and subtropics (Oyaizu et al., 1993). The subfamily Mimosoideae seems to have branched earlier than the subfamily Papilionoideae in the evolution of the family Leguminosae (Doyle, 1995), and less is known about symbiotic bacteria from the Mimosoideae than from the Papilionoideae. Leucaena, Acacia and Mimosa are genera within the subfamily Mimosoideae. Rootnodule isolates from species within the genera Leucaena and Acacia have been found to be highly diverse (Dupuy et al., 1994; Wang et al., 1999b; de Lajudie et al., 1994, 1998a). Rhizobium strains from Mimosa caesalpiniaefolia were isolated by Campelo \& Dobereiner (1969). Extensive isolations were made by 
Table 1. Isolates and strains used in this study and their relevant characteristics

\begin{tabular}{|c|c|c|c|}
\hline Isolate or strain & $\begin{array}{l}\text { SSU rRNA } \\
\text { PCR-RFLP } \\
\text { pattern* }\end{array}$ & $\mathbf{E T} \dagger$ & Plasmid profile (kbp) + \\
\hline \multicolumn{4}{|l|}{ Isolates from $M$. affinis in Huautla } \\
\hline $\begin{array}{l}\operatorname{Mim} 2, \operatorname{Mim} 5, \operatorname{Mim} 6, \operatorname{Mim} 8, \operatorname{Mim} 10, \\
\text { Mim1-1, Mim1-3, Mim3-4, Mim3- } \\
\text { 6, Mim4-4, Mim4-5, Mim6-2, } \\
\text { Mim6-3 }\end{array}$ & DBEC & 2 & $390,450,600,1000$ \\
\hline Mim1-2 & DBEC & 2 & $390,450,600,>1000$ \\
\hline Mim1-4, Mim8-5, Mim10-2 & DBEC & 2 & $390,600,1000$ \\
\hline $\operatorname{Mim} 7-5$ & DBEC & 2 & $100,390,450,600,1000$ \\
\hline $\begin{array}{l}\text { Mim2-3, Mim2-4, Mim2-5, Mim2-6, } \\
\text { Mim6-4, Mim6-5, Mim7-2, Mim7- } \\
\text { 3, Mim9-3, Mim9-4, Mim10-3, } \\
\text { Mim10-4 }\end{array}$ & DBEC & 2 & ND \\
\hline $\operatorname{Mim} 7-4$ & DBEC & 3 & $200,350,530,630,800$ \\
\hline $\begin{array}{l}\text { Mim3-5, Mim3-7, Mim4-2, Mim4-3, } \\
\text { Mim5-2, Mim5-3, Mim5-4, Mim5- } \\
\text { 5, Mim8-2 }\end{array}$ & DBEC & 4 & $390,510,600,1000$ \\
\hline $\begin{array}{l}\text { Mim8-3, Mim8-4, Mim9-2, Mim9-5, } \\
\text { Mim10-1 }\end{array}$ & DBEC & 4 & ND \\
\hline Mim1, Mim7, Mim11, Mim12 & DBEC & 5 & $185,300,300,510,600,900$ \\
\hline $\operatorname{Mim} 9$ & DBEC & 5 & ND \\
\hline \multicolumn{4}{|l|}{ Isolates from $M$. affinis in Cuernavaca soil } \\
\hline $\mathrm{MimC1}$ & CBEC & ND & ND \\
\hline $\mathrm{MimC2}$ & CBEC & ND & ND \\
\hline \multicolumn{4}{|l|}{ Reference strains } \\
\hline R. etli $\mathrm{CFN} 42^{\mathrm{T}}$ & DBEC & 6 & $150,175,270,390,510,630$ \\
\hline R. etli $\mathrm{F} 8$ & ND & 1 & ND \\
\hline R. etli Bra5 & ND & 2 & ND \\
\hline R. etli Viking1 & ND & 7 & ND \\
\hline R. tropici CFN299 & EBFD & 8 & $185,225, \mathbf{4 1 0},>1000$ \\
\hline R. tropici CIAT $899^{\mathrm{T}}$ & FBDB & ND & ND \\
\hline R. leguminosarum USDA $2370^{\mathrm{T}}$ & DBDB & ND & ND \\
\hline R. galegae HAMBI $540^{\mathrm{T}}$ & IBDF & ND & ND \\
\hline R. gallicum $\mathrm{R} 602 \mathrm{sp}^{\mathrm{T}}$ & CBAD & ND & ND \\
\hline R. giardinii $\mathrm{H} 152^{\mathrm{T}}$ & AAAI & ND & ND \\
\hline Rhizobium sp. Lc37 & CBEC & ND & ND \\
\hline M. loti $\mathrm{NZP} 2213^{\mathrm{T}}$ & GGFF & $\mathrm{ND}$ & ND \\
\hline M. huakuii CCBAU2609 ${ }^{\mathrm{T}}$ & FHGF & ND & ND \\
\hline M. ciceri USDA $3378^{\mathrm{T}}$ & GGFF & ND & ND \\
\hline M. mediterraneum USDA $3392^{\mathrm{T}}$ & HGGF & ND & ND \\
\hline Sinorhizobium sp. Lc28 & ADEA & $\mathrm{ND}$ & ND \\
\hline S. meliloti USDA $1002^{\mathrm{T}}$ & ADAA & ND & ND \\
\hline S. fredii USDA $205^{\mathrm{T}}$ & EDAA & ND & ND \\
\hline
\end{tabular}

* RFLP patterns of SSU rRNA gene PCR-fragments digested individually with restriction enzymes MspI, HinfT, HhaI and Sau3AI are indicated by four letters. Agarose gels (3\%) in $0.5 \times$ TBE buffer were used for separation of the digests.

$\dagger$ ETs were designated according to the combination of electrophoretic patterns of 10 metabolic enzymes in starch gels.

$\ddagger$ Plasmid patterns were detected in Eckhardt gels $(0.75 \%$ agarose $)$ and the sizes of the plasmids were estimated from their migration distances using the computer program SEQAID II version 3.5 (Rhoads \& Roufa, 1989) and the plasmids of $R$. etli CFN42 (Romero et al., 1991) and $R$. tropici CFN299 (Geniaux et al., 1995; Martínez et al., 1987) as molecular size standards. The symbiotic plasmids identified by nif gene probing are marked in bold.

ND, Not done. 
Trinick (1980) from Mimosa invisa and Mimosa pudica. Some of these isolates were capable of nodulating and fixing nitrogen in Leucaena, and the reverse was also true. Four isolates from $M$. invisa and $M$. pudica nodules obtained from the Philippines were similar to Rhizobium leguminosarum and Bradyrhizobium japonicum and to a new lineage related to R. galegae, on the basis of comparison of $16 \mathrm{~S}$ rRNA gene sequences (Oyaizu et al., 1993).

In Rhizobium species, a significant proportion of the genome and its diversity is composed of plasmids, with the genetic information for nodulation and nitrogen fixation being located on the so-called symbiotic plasmids (reviewed by Martínez et al., 1990). Specifically, a number of nod genes involved in the production of Nod factors (Dénarié et al., 1996), which are key signal molecules in nodule formation (Relic et al., 1994), and nifHDK genes that encode for nitrogenase are located on the symbiotic plasmids. Symbiotic plasmids may be transferred among Rhizobium species as well as to related genera, such as Agrobacterium, under laboratory conditions (Martínez et al., 1987; Novikova \& Safronova, 1992). Plasmid transfer in natural rhizobial populations has been assessed by comparing chromosomal and plasmid phylogenies (Amarger et al., 1997; Haukka et al., 1998; Souza \& Eguiarte, 1997), and some earlier literature was reviewed by Martínez-Romero (1994) and MartínezRomero \& Caballero-Mellado (1996). Recently, the complete nucleotide sequence of a very-broad-hostrange symbiotic plasmid showed that different genes in this plasmid may have different origins, suggesting a chimeric nature for symbiotic plasmids (Freiberg et al., 1997).

Phaseolus vulgaris has been documented as a promiscuous host for rhizobia (Martínez et al., 1985) and diverse bean-nodulating rhizobia have been recorded (van Berkum et al., 1996; Eardly et al., 1995; Geniaux et al., 1993; Hernández-Lucas et al., 1995; Laguerre et al., 1993). Species in which strains have originated from bean plants include Rhizobium etli (Segovia et al., 1993), Rhizobium gallicum (Amarger et al., 1997), Rhizobium giardinii (Amarger et al., 1997), R. leguminosarum and Rhizobium tropici (Martínez-Romero et al., 1991). Strains within $R$. mongolense (van Berkum et al., 1998) and various Sinorhizobium species (summarized by Hernández-Lucas et al., 1995) were isolated from other host plants, but they also nodulated bean plants. In the reported phylogenetic trees based on the full SSU rRNA gene sequence (such as Amarger et al., 1997; Wang et al., 1998, 1999a), R. etli was closer to $R$. leguminosarum than to other species, and this was also the case when nodD gene sequences of $R$. leguminosarum bv. phaseoli and $R$. etli were compared (Laguerre et al., 1996).

To describe more completely the diversity of $R h i-$ zobium from tropical areas, we isolated and analysed symbiotic bacteria from Mimosa affinis, a legume species native to Sierra de Huautla, a rainforest nature reserve in central Mexico. $M$. affinis is a small, annual plant that has never been domesticated and whose symbiotic bacteria have not been characterized. Our results showed that they corresponded to a limited group of lineages within $R$. etli, the dominant symbiotic bacterium for Phaseolus vulgaris (Segovia et al., 1993; Caballero-Mellado \& Martínez-Romero, 1999). Thus, we considered it of interest to pursue the molecular comparison of symbionts from $P$. vulgaris and $M$. affinis, with the aim of better understanding how Rhizobium lineages diverge and diversify.

\section{METHODS}

Nodule isolation and culture. Eleven $M$. affinis plants were collected from two populations $20 \mathrm{~km}$ apart in Sierra de Huautla, and one plant was grown in Cuernavaca soil. Nodules were surface-sterilized and were crushed on PY (3 g yeast extract, $5 \mathrm{~g}$ peptone and $0.7 \mathrm{~g}$ calcium chloride $1^{-1}$ ) plates. Bacterial isolates and reference strains (Table 1) were maintained in YM medium stabs (Vincent, 1970). Melanin production was detected in cultures grown on semi-solid PY

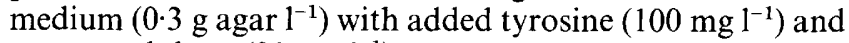
copper sulphate $\left(20 \mathrm{mg} \mathrm{l}^{-1}\right)$.

Plant nodulation tests. Seeds of Leucaena leucocephala cv. Peruvian and Phaseolus vulgaris cv. Negro Xamapa were surface-sterilized (Martínez et al., 1985) and pre-germinated seeds were placed in flasks with cotton or vermiculite with $\mathrm{N}$ free plant nutrient solution (Fåhraeus, 1957). Plants were maintained in growth chambers at $28^{\circ} \mathrm{C}$ with a photoperiod of $15 \mathrm{~h}$. Nodulation of the plants was observed after 4 weeks of growth and the nitrogen-fixation ability of the nodules was assessed by comparison of the leaf colour of the inoculated plants with control plants that were not inoculated.

SSU rRNA gene typification. Primers fD1 and rD1 (Weisburg et al., 1991) were used to synthesize SSU rRNA gene fragments by PCR with Taq polymerase. The PCR fragments were digested individually with restriction enzymes MspI, Sau3AI, HinfI and HhaI and the RFLP of the amplified SSU rRNA genes were visualized in agarose gels as described by Laguerre et al. (1994). Patterns were compared with type strains from the majority of described Rhizobium, Sinorhizobium and Mesorhizobium species. The RFLP of the rRNA operons were determined by hybridizing Southern blots of EcoRI digests with a PCR product of the full 16S rRNA gene from Bradyrhizobium japonicum USDA6.

Multilocus enzyme electrophoresis (MLEE). Cell extracts from the new isolates and from reference strains were prepared from $40 \mathrm{ml}$ liquid cultures in PY medium. The following metabolic enzymes were assayed: isocitrate, malate, alanine, threonine and glucose-6-phosphate dehydrogenases, hexokinase, phosphoglucomutase, indophenol oxidase and esterase. Enzymic activities were revealed with the standard procedures described by Selander et al. (1986). The mean genetic diversity for a locus was calculated as $h=$ $\left[1-\Sigma x_{i}^{2}\right][n /(n-1)]$, where $x_{\mathrm{i}}$ is the frequency of the $i$-th allele at the locus and $n$ is the number of electrophoretic types (ETs) in the sample. Mean diversity $(\mathrm{H})$ is the arithmetic mean of $h$ over all loci assayed. A cluster analysis was performed using the neighbour-joining method (Nei \& $\mathrm{Li}$, 
Table 2. Plasmids used in this study

\begin{tabular}{|c|c|}
\hline Plasmid & Description \\
\hline pEM15 & $\begin{array}{l}\text { pSUP205 derivative with nifKDH of } R \text {. etli } \\
\text { CFN42 (Morett et al., 1988) }\end{array}$ \\
\hline $\mathrm{pH} 3$ & $\begin{array}{l}\text { pSUP202 derivative containing the replicator } \\
\text { region (RepA, Rep } B, \operatorname{Rep} C \text { genes and } \\
\text { intergenetic sequences) of } \mathrm{p} 42 \mathrm{~d} \text { in a } 5 \cdot 6 \mathrm{kbp} \\
\text { HindlII fragment (Ramirez-Romero et al., } \\
\text { 1997) }\end{array}$ \\
\hline pKRE-1 & $\begin{array}{l}\text { Cosmid (M. A. Cevallos, unpublished); the } \\
\text { same fragment as outlined for pH3 was cloned } \\
\text { in pRK } 7813 \text {, a wide-host-range vector (Stanley } \\
\text { et al., 1987) }\end{array}$ \\
\hline pAGS10 & $\begin{array}{l}3.6 \mathrm{kbp} E c o \mathrm{RI}-\text { Bam } \mathrm{HI} \text { fragment containing the } \\
\text { entire } l p s \beta 1 \text { and } l p s \beta 2 \text { region of CFN42 } \\
\text { plasmid b cloned in pRK } 7813, \mathrm{Tc}^{\mathrm{r}} \text { (Garcia-de } \\
\text { los Santos \& Brom, 1997) }\end{array}$ \\
\hline pAGS4 & $\begin{array}{l}718 \text { bp internal fragment (XhoI-Bam } \mathrm{HI} \text { ) of } \\
\text { lps } \beta 2 \text { from pAGS10 cloned in pBluescript II } \\
\mathrm{SK}(-), \mathrm{Cb}^{\mathrm{r}} \text { (Garcia-de los Santos \& Brom, } \\
\text { 1997) }\end{array}$ \\
\hline pUC19 & Cloning vector (Sambrook et al., 1989) \\
\hline pRK2013 & $\begin{array}{l}\text { Helper plasmid for conjugation, } \mathrm{Km}^{\mathrm{r}} \text { (Ditta et } \\
\text { al., 1980) }\end{array}$ \\
\hline
\end{tabular}

1979) based on the genetic distance data and a dendrogram was constructed. Linkage disequilibrium was calculated as described previously (Souza et al., 1992).

Plasmid analysis. The cellular plasmid contents of some isolates were visualized in $0.75 \%$ agarose gels by a modified Eckhardt technique (Hynes \& McGregor, 1990). Plasmids of R. etli CFN42 (Romero et al., 1991) and $R$. tropici CFN299 (Geniaux et al., 1995; Martínez et al., 1987) were used as molecular size standards and as positive controls for hybridization analyses. The electrophoretic plasmid patterns were hybridized as described previously (Wang et al., 1998) to the following probes labelled with $\left[{ }^{32} \mathrm{P}\right] \mathrm{dCTP}$ (Amersham) : a $600 \mathrm{bp}$ internal $\mathrm{Sal}$ I fragment of nif $H$ from pEM15 (Morett et al., 1988), a $5.6 \mathrm{kbp}$ HindIII fragment from $\mathrm{pH} 3$ containing the replicator region of CFN42 plasmid d (Ramírez-Romero et al., 1997), a PCR-amplified internal lipopolysaccharide gene (lps $\beta 1)$ fragment $(250 \mathrm{bp}$ ) from pAGS10 (García-de los Santos \& Brom, 1997) and pAGS4, in which a $0.718 \mathrm{kbp}$ internal fragment of $\operatorname{lps} \beta 2$ was cloned (Garcia-de los Santos \& Brom, 1997) (Table 2).

DNA fingerprinting and hybridization. DNA was isolated by standard methods (Sambrook et al., 1989) from representative isolates and reference strains. DNA fingerprinting patterns were visualized after electrophoretic separation in $1.0 \%$ agarose gels of fragments digested with the restriction enzymes BamHI or EcoRI. $\lambda$ DNA digested with BstEII was used as the molecular size marker for estimation of fragment sizes in hybridization tests. The DNA restriction products were transferred to Hybond- $\mathrm{N}^{+}$membranes (Amersham) and hybridized under stringent conditions at $65^{\circ} \mathrm{C}$. The probes used for plasmid hybridization were also used for this experiment. Additional probes to evaluate DNA-DNA homology were total DNA digested with EcoRI from either
CFN42 or Mim2 used in filter DNA hybridization, as described previously (Wang et al., 1998).

nifH gene sequence. PCR products were obtained from a representative isolate, $\mathrm{Mim} 2$, using $P$ wo DNA polymerase (Boehringer) and primers nifH-1 and nifH-2, corresponding to nucleotides 256 and 856 of the Sinorhizobium meliloti nifH gene (Eardly et al., 1992). The PCR products were checked by electrophoresis in $1 \%$ agarose and were purified from the gel using a Nucleotrap extraction kit for nucleic acids. The PCR fragments were cloned in the SmaI site of pUC19 vector (Sambrook et al., 1989) by using the PCR cloning kit (blunt-end) from Boehringer as specified by the manufacturer and the resulting clones were extracted using the High Pure plasmid isolation kit (Boehringer) and sequenced using an AutoRead sequencing kit on an ALF DNA sequencer (Pharmacia). The sequence obtained from Mim2 was compared with other sequences in the database. Sequences were aligned using the PILEUP program in the Wisconsin package version 8.1 (Genetics Computer Group, 1995). The neighbour-joining method and bootstrap analysis (confidence values estimated from 500 replications of each sequence) in the CLUSTAL w package (Thompson et al., 1994) were used to produce a phylogenetic tree. The following nifH sequences from GenBank were used: Mesorhizobium sp. DWO366 (Z95226), R. etli CFN42 (M15941), R. etli Olivia 4 (M55227), R. gallicum FL27 (M55226), R. leguminosarum bv. trifolii (K00490), Rhizobium sp. BR6001 (Z95230), $R$. tropici CIAT899 (M55225), Sinorhizobium fredii USDA191 (Z95229), S. meliloti CC169 (M55231), Sinorhizobium saheli ORS609 (Z95221) and Sinorhizobium terangae ORS1009 (Z95218).

Matings. Transconjugants of $\mathrm{Mim} 1$, a representative isolate from $M$. affinis, were obtained by transferring $\operatorname{Tn} 5-m o b$ labelled plasmids (a-f) from CFN42 derivatives (Brom et al., 1992) in triparental matings using plasmid pRK2013 as a helper. Transconjugants were selected by their resistance to kanamycin $\left(50 \mu \mathrm{g} \mathrm{ml}^{-1}\right)$. Nodulation tests were performed for the transconjugants containing two symbiotic plasmids from both the donor (CFN42) and the receptor (Miml) on $P$. vulgaris and $L$. leucocephala plants. pKRE-1 (M. A. Cevallos, unpublished), a cosmid containing the replicator region of the symbiotic plasmid, plasmid d, of CFN42, was introduced into isolates Mim1, Mim7-4 and Mim7-5 and transconjugants were selected by their resistance to tetracycline $\left(3 \mu \mathrm{g} \mathrm{ml}^{-1}\right)$.

\section{RESULTS}

\section{Isolation and phenotypic characteristics}

One hundred and forty isolates were obtained from the nodules on $11 M$. affinis plants collected from Huautla and two isolates were obtained from one plant grown in soil from Cuernavaca. All the isolates from Huautla had the same colony morphology and growth rate on PY medium. All of them formed gummy and pearly colonies $>2 \mathrm{~mm}$ in diameter after $3 \mathrm{~d}$ incubation on PY plates. Colonies of the two isolates from Cuernavaca soil were not gummy. Fifty isolates from Huautla were chosen randomly for further characterization.

The 50 selected Rhizobium isolates from Huautla and reference strains for $R$. etli (Table 1) were resistant to 
nalidixic acid $\left(20 \mu \mathrm{g} \mathrm{ml}^{-1}\right)$ and did not grow in LB. These isolates had duplication times of $3 \mathrm{~h}$ in PY liquid medium, similar to $R$. etli strains. No melanin production was obtained from the isolates even after 1 month incubation in soft agar containing tyrosine and copper, while CFN42 readily produced the brown pigment.

\section{Nodulation tests}

All 50 isolates from $M$. affinis obtained in Huautla were capable of nodulating $P$. vulgaris cultivar Negro Xamapa, with nodules appearing around 5-6 d after inoculation. The mean number of nodules per plant ranged from 30 , in the case of inoculation with isolate Mim5, to 60, in the case of inoculation with isolate Mim1, after $17 \mathrm{~d}$. The nodules were pink and the leaves of the nodulated plants were dark-green, as were the positive controls inoculated with $R$. etli $\mathrm{CFN} 42$, while the control non-inoculated plants were yellow-green. Isolates Mim1, Mim2, Mim3-7, Mim7 and Mim7-4 formed nodules on L. leucocephala and nodulated plants were green, while non-inoculated plants or those inoculated with $R$. etli strains CFN42 and F8 did not have nodules and were yellow.

\section{Ribosomal types}

The ribosomal types were defined on the basis of the PCR-RFLP and RFLP patterns of SSU rRNA genes. RFLP patterns of PCR-synthesized SSU rRNA genes were identical in $R$. etli strain CFN42 and in all 50 isolates from Huautla, and differed from those of $R$. tropici CIAT899 and CFN299, S. meliloti USDA1002, R. galegae HAMBI540, Mesorhizobium loti NZP2213, $R$. leguminosarum USDA2370, $M$. huakuii CCBAU2609, $M$. ciceri USDA3378, $M$. mediterraneum USDA3392, $S$. fredii USDA205, $R$. gallicum FL27 and $R$. giardinii $\mathrm{H} 152$ (Table 1). The two strains isolated from $M$. affinis sown in Cuernavaca soil had patterns identical to each other and to one of our previously isolated strains from Leucaena (Lc37), which corresponded to a novel lineage within the genus Rhizobium (Wang et al., 1999b) (Table 1). Additional characteristics of these two isolates from Cuernavaca will be reported elsewhere and only the characterization of the isolates from Huautla is presented here. Hybridization patterns (RFLPs) of EcoRI-restricted DNAs to the 16S rRNA gene were identical in $R$. etli CFN42 and in the isolates from $M$. affinis obtained in Huautla (not shown).

\section{Electrophoretic types}

The 50 isolates from $M$. affinis in Huautla were grouped into four ETs (ET 2-5) (Table 1) based on the analysis of ten enzymes. ETs 3, 4 and 5 were composed only of isolates from $M$. affinis, corresponding to one, 14 and five isolates in each. ET 2 contained 30 isolates and a reference strain, Bra5. The other reference strains

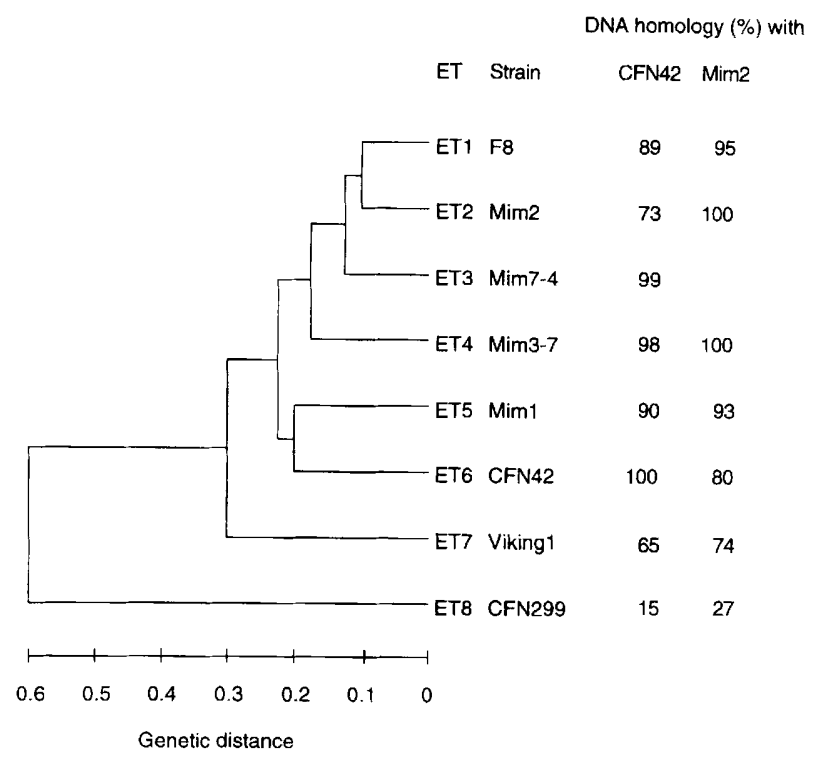

Fig. 1. Genetic relatedness of isolates from $M$. affinis, $R$. etli reference strains and $R$. tropici CFN299 defined by analyses of MLEE and DNA-DNA homology. The dendrogram was constructed from the MLEE data for 10 metabolic enzymes using the neighbour-joining method (Nei \& $\mathrm{Li}$, 1979) based on the genetic distance (Selander et al., 1986) of each ET pair. ET 2 contains 30 isolates and strain Bra5; ET 3 contained isolate Mim7-4 only; ET 4 represents 14 isolates; ET 5 consists of five isolates. DNA-DNA homology was estimated by the filterhybridization method (Wang et al., 1998).

for $R$. etli, CFN42, F8 and Viking1, and R. tropici CFN299 formed distinct ETs. The isolates from $M$. affinis and the reference strains for $R$. etli were intermingled in a close cluster (genetic distance less than 0.3 ) that was distant from $R$. tropici strain CFN299 (genetic distance 0.6) (Fig. 1). We obtained a mean of 12.5 isolates per ET among the isolates from M. affinis, which is larger than the mean of 1.2 obtained with isolates from $P$. vulgaris (Pérez-Ramírez et al., 1998). The mean genetic diversity $(H)$ for ETs from Mimosa was $0 \cdot 2$. ETs of the isolates and reference strains for $R$. etli were in linkage equilibrium, with the $\mathrm{V}_{\mathrm{o}} / \mathrm{V}_{\mathrm{e}}$ value $(0 \cdot 951)$ close to 1 , meaning that the microsymbionts of $M$. affinis and $P$. vulgaris share a pool of chromosomal genes with no barriers for chromosomal recombination.

\section{DNA-DNA homology and fingerprinting}

In agreement with the MLEE results, we found close similarity of isolates from $M$. affinis and $R$. etli reference strains from $P$. vulgaris on the basis of DNA-DNA homology (Fig. 1). When total DNA from $R$. etli $\mathrm{CFN} 42$ was used as a probe in three independent assays, the homology was $73-99 \%$ with isolates Mim2, Mim7-4, Mim3-7 and Mim1, representing ETs 2, 3, 4 and 5, respectively; homology was lower with Viking1 $(65 \%)$ and $R$. tropici CFN299 


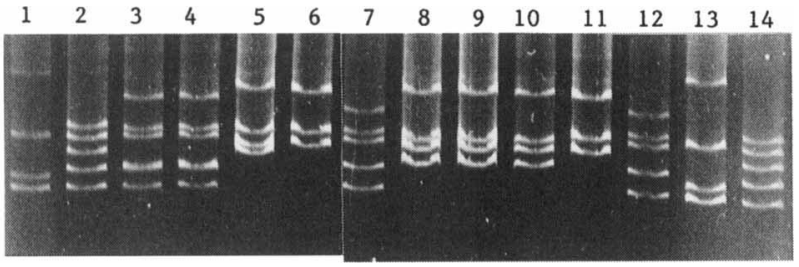

Fig. 2. Examples of plasmid profiles of isolates from $M$. affinis obtained in Huautla (lanes 3-12). Lanes: 3, Mim1 $(185,300,300$, $510,600,900 \mathrm{kbp}) ; 4, \operatorname{Mim} 7$ (sizes as lane 3); 5, Mim1-3 (390, $450,600,1000) ; 6, \operatorname{Mim} 1-4(390,600,1000) ; 7, \operatorname{Mim} 7-4(200$, $350,530,630,800) ; 8, \operatorname{Mim5}-4(390,510,600,1000) ; 9$, Mim4-3 (as lane 8); 10, Mim4-2 (as lane 8); 11, Mim8-5 (as lane 6); and 12. Mim7-4 (as lane 7). Molecular sizes were estimated from migration distances using the computer program SEQAID II version 3.5 (Rhoads \& Roufa, 1989) and the plasmids of $R$. tropici CFN299 (lanes 1 and 13) $(185,225,410,>1000 \mathrm{kbp}$ ) (Geniaux et al., 1995; Martínez et al., 1987) and $R$. etli CFN42 (lanes 2 and 14) $(150,270,390,510,630 \mathrm{kbp})$ (Romero et al., 1991) as molecular size markers.

$(15 \%)$. When DNA from isolate Mim2 was used as a probe (two independent assays), homology with $R$. etli strains CFN42 and F8 was 80 and $95 \%$.

Identical DNA fingerprints were obtained from the restriction of total DNA with EcoRI among some isolates within an ET, and these patterns were similar among related ETs (not shown), predominantly in the lower parts of the gels, as observed previously for related ETs of Acetobacter diazotrophicus (CaballeroMellado \& Martínez-Romero, 1994).

\section{Plasmid profiles and symbiotic plasmid characterization}

All isolates from $M$. affinis tested had plasmids (Table 1) ranging from $100 \mathrm{kbp}$ to larger than $1000 \mathrm{kbp}$. Different plasmid patterns were observed (Fig. 2). Megaplasmids ( $\geqslant 1000 \mathrm{kbp})$ were observed in all the isolates tested from ETs 2 and 4. Plasmid profiles seemed to be conserved in genetically related isolates. Nine isolates within ET 4 shared the same plasmid pattern, and the four isolates in ET 5 had another identical pattern. Although four different plasmid patterns (with three to five plasmids in each) were obtained in 17 ET 2 isolates, two common bands ( 390 and $600 \mathrm{kbp}$ ) were observed in all of them. The $600 \mathrm{kbp}$ plasmid was common to all the isolates tested within ETs 2, 4 and 5, but was not observed in Mim7-4, the only isolate in ET 3.

The symbiotic plasmids, identified by hybridization of Eckhardt gels to R. etli nif genes, were $600 \mathrm{kbp}$ in most of the isolates from $M$. affinis tested (Mim1-1, Mim13, Mim1-4, Mim8-5, Mim4-2, Mim4-3, Mim5-4, Mim1 and Mim7, representing ETs 2, 4 and 5) and slightly larger (630 kbp) in Mim7-4, the sole isolate corresponding to ET 3. Multiple copies of the nifH gene were observed in the isolates and in $R$. etli reference

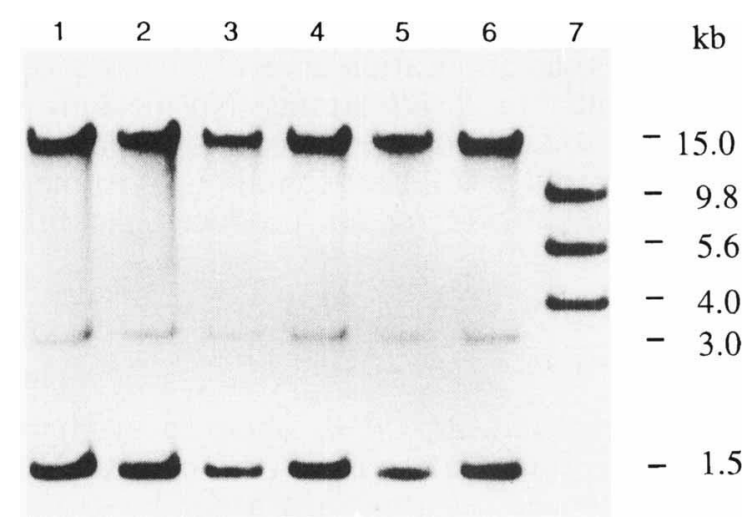

Fig. 3. Example of autoradiogram of nifH gene hybridization patterns obtained in BamHI digests of DNAs from the isolates and a reference strain. Lanes: 1 , Mim3-7; $2, \operatorname{Mim} 1-1 ; 3, \operatorname{Mim} 7-5$; 4, Mim5-3; 5, Mim10-4; 6, Mim9-2; 7, R. etli CFN42 (Martínez et al., 1985). Isolates Mim1, Mim5, Mim2-5, Mim5-5, Mim7-2, Mim7, Mim12, Mim1-3, Mim3-6, Mim4-2, Mim6-4, Mim8-3, Mim9-5 and Mim10-1 gave patterns identical to those of Mim37. The molecular mass marker was $\lambda$ DNA digested with BstEll and the sizes of the hybridizing bands were estimated using the computer program SEQAID II version 3.5 (Rhoads \& Roufa, 1989).

strains (Fig. 3). The nifH gene organization was the same in all isolates from $M$. affinis tested representing ETs 2, 4 and 5, which had symbiotic plasmids with the same molecular size, and different from that found in $R$. etli strains from $P$. vulgaris (Fig. 3). Two strongly hybridizing bands of around 15 and $1.5 \mathrm{kbp}$ and one faint band $(3.0 \mathrm{kbp})$ were obtained from the isolates (Fig. 3).

The replicator region of the symbiotic plasmid, pSym, from $R$. etli strain CFN42 (Ramírez-Romero et al., 1997) did not hybridize to any plasmid in isolates Mim1, Mim5-5, Mim7-4 or Mim7-5, representing the four ETs. Furthermore, the introduction of plasmid pKRE-1 carrying this replicator did not promote any plasmid loss in Mim7-4 (ET 3) or Mim7-5 (ET 2), but a $300 \mathrm{kbp}$ plasmid was lost upon introduction of pKRE-1 in Mim1 (ET 5).

Two clones each containing a PCR-amplified fragment from Mim2 nifH gene were sequenced. Over the nucleotides compared, both clones had identical sequences. The sequence identities among the nifH gene obtained from isolate Mim2 and those from related species obtained from GenBank are presented in Table 3. A dendrogram showing nifH sequence relatedness is shown in Fig. 4. The Mim2 nifH gene is closely related to the $R$. etli CFN42 nifH gene $(97 \cdot 3 \%$ identity in nucleotide sequences, $98.9 \%$ identity in amino acid sequences). R. gallicum bv. gallicum, $R$. etli CFN42, R. etli Olivia 4 and the isolate Mim2 formed a close cluster that was supported by high bootstrap values (Fig. 4). Their sequence identities were greater than $95.7 \%$, while they had identities to other species of $83 \cdot 5-90 \cdot 5 \%$. 
Table 3. Sequence identities ( $\%$ ) of internal nifH gene fragments (558 bp) among $R$. et/i bv. mimosae Mim2 and related strains

Sequences were aligned and compared using SEQED and GAP programs in the Wisconsin package.

\begin{tabular}{|c|c|c|c|c|c|c|c|c|c|c|c|c|}
\hline & 1 & 2 & 3 & 4 & 5 & 6 & 7 & 8 & 9 & 10 & 11 & 12 \\
\hline 1. R. etli $\operatorname{Mim} 2$ & 100 & & & & & & & & & & & \\
\hline 2. R. etli CFN42 & $97 \cdot 3$ & 100 & & & & & & & & & & \\
\hline 3. R. etli Olivia 4 & $97 \cdot 3$ & $100 \cdot 0$ & 100 & & & & & & & & & \\
\hline 4. R. gallicum FL27 & $96 \cdot 1$ & $95 \cdot 7$ & $95 \cdot 7$ & 100 & & & & & & & & \\
\hline 5. $R$. tropici CIAT899 & $90 \cdot 2$ & $89 \cdot 4$ & $89 \cdot 4$ & $90 \cdot 4$ & 100 & & & & & & & \\
\hline 6. Rhizobium sp. Br6001 & $90 \cdot 5$ & $89 \cdot 8$ & $89 \cdot 8$ & $90 \cdot 6$ & $97 \cdot 0$ & 100 & & & & & & \\
\hline 7. R. leguminosarum & $84 \cdot 1$ & $83 \cdot 5$ & $83 \cdot 5$ & $83 \cdot 1$ & $82 \cdot 3$ & $82 \cdot 6$ & 100 & & & & & \\
\hline 8. S. meliloti & $86 \cdot 6$ & $86 \cdot 6$ & $86 \cdot 6$ & $87 \cdot 4$ & $86 \cdot 6$ & $87 \cdot 0$ & $83 \cdot 3$ & 100 & & & & \\
\hline 9. S. terangae ORS1009 & $89 \cdot 6$ & $88 \cdot 7$ & $88 \cdot 7$ & $90 \cdot 2$ & $88 \cdot 8$ & $88 \cdot 9$ & $83 \cdot 7$ & $88 \cdot 0$ & 100 & & & \\
\hline 10. S. saheli ORS609 & $88 \cdot 7$ & $88 \cdot 3$ & $88 \cdot 3$ & $88 \cdot 4$ & $87 \cdot 2$ & $88 \cdot 2$ & $83 \cdot 7$ & $87 \cdot 8$ & 94.3 & 100 & & \\
\hline 11. S. fredii USDA191 & $90 \cdot 3$ & $90 \cdot 0$ & $90 \cdot 0$ & $91 \cdot 7$ & $89 \cdot 2$ & $88 \cdot 9$ & $83 \cdot 9$ & $88 \cdot 4$ & $91 \cdot 4$ & $90 \cdot 7$ & 100 & \\
\hline 12. Mesorhizobium sp. DWO366 & $89 \cdot 8$ & $89 \cdot 6$ & $89 \cdot 6$ & $90 \cdot 4$ & $89 \cdot 0$ & $90 \cdot 0$ & $82 \cdot 2$ & $87 \cdot 2$ & $88 \cdot 9$ & $88 \cdot 9$ & $89 \cdot 8$ & 100 \\
\hline
\end{tabular}

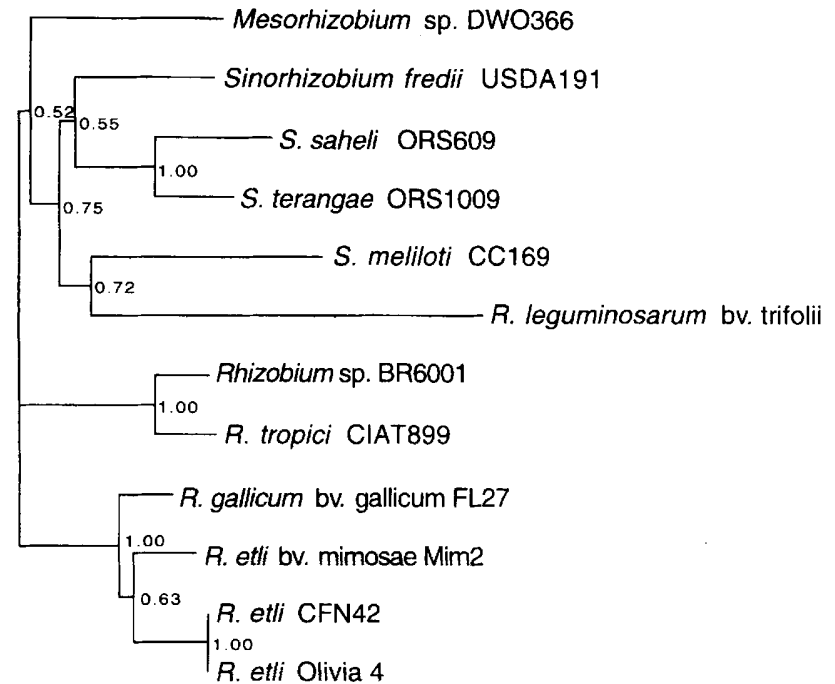

$5 \%$ divergence

Fig. 4. Phylogram showing relatedness of partial nifH gene sequences of isolate Mim2, a representative of the 50 isolates from $M$. affinis obtained in Huautla, and reference strains. Sequences were aligned using the PILEUP program in the GCG package. The neighbour-joining method in the CLUSTAL $W$ package (Thompson et al., 1994) was used for the analysis of sequence data. Bootstrap confidence values were estimated from 500 replications of each sequence.

\section{General plasmid comparison}

By hybridization with plasmid patterns, genes homologous to $l p s \beta$ were found either on a plasmid similar in size $(185 \mathrm{kbp})$ to plasmid $\mathrm{b}$ of $R$. etli CFN42 (175 kbp), in isolates Miml and Mim7 (ET 5), or on a megaplasmid (1000 kbp), in Mim1-4, Mim7-5 (ET 2)

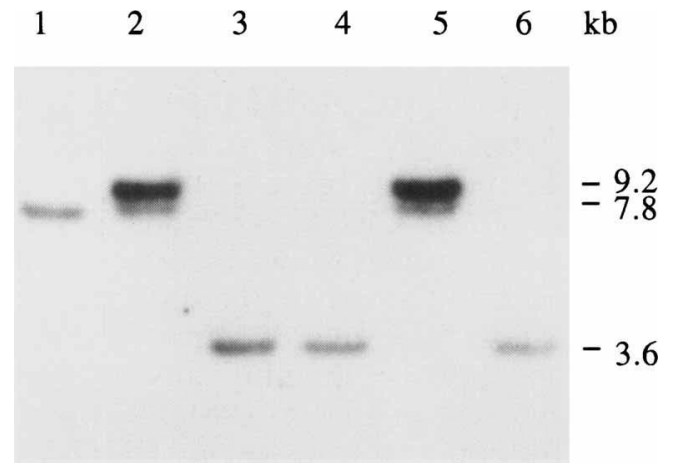

Fig. 5. Hybridization patterns of $\mid p s \beta 1$ gene ( $250 \mathrm{bp} P C R$ fragment of pAGS10) from $R$. etli CFN42 to ECoRI digests of DNAs from new isolates and $R$. etli CFN42. Lanes: 1, CFN42; 2 , Mim1; 3, Mim1-4; 4, Mim4-3; 5, Mim7; 6, Mim7-5. $\lambda$ DNA digested with HindIII was used as the molecular size marker to estimate the sizes of the hybridizing bands.

and Mim4-3 (ET 4) (not shown). Two restriction patterns ( 1 and 2$)$ were observed in the hybridization of EcoRI-digested total DNA from isolates Miml-4, Mim7-5 (ET 2), Mim4-3 (ET 4), Mim1 and Mim7 (ET 5 ), representing different plasmid patterns, to $R$. etli CFN42 lps $\beta$ genes (Fig. 5). Hybridization pattern 1 had two hybridizing bands $(9 \cdot 2$ and $7 \cdot 8 \mathrm{kbp})$ and was found in the isolates of ET 5 from $M$. affinis that have homology to $\operatorname{lps} \beta 1$ on a $185 \mathrm{kbp}$ plasmid. Only one hybridizing band $(3.6 \mathrm{kbp})$, which we designated pattern 2, was obtained from the isolates of ET 2 and ET 4. These isolates were found to have the $\operatorname{lps} \beta$ genes located on megaplasmids ( $1000 \mathrm{kbp})$. Identical hybridization results were obtained with the two $\operatorname{lp} s \beta$ gene probes (lps $\beta 1$ and 2), which demonstrated that the two $l p s \beta$ genes were in one gene cluster in the isolates, as for those in CFN42. 


\section{Conjugal transfer of plasmids}

We transferred each of the six plasmids $(\mathrm{a}-\mathrm{f})$ from strain CFN42 (Brom et al., 1992) to the isolate Miml. Ten transconjugants (colonies) from each plasmid transfer were analysed. Plasmids a, b, c, d and e (150, $175,270,390$ and $510 \mathrm{kbp}$, respectively) could be transferred easily to Mim1 receptors. We found that plasmids $a$ and $b$ were maintained in Mim1 transconjugants. It seems that CFN42 plasmids $\mathrm{c}$ and $\mathrm{e}$ substitute for the similarly sized plasmids ( 300 and $510 \mathrm{kbp}$, respectively) in isolate Mim1, since Tn5 was maintained but the plasmid profiles were not changed and the hybridizations to Tn5-mob were obtained in the 270 and $510 \mathrm{kbp}$ plasmids in the transconjugants. The CFN42 symbiotic plasmid, plasmid d, was maintained in Miml in all 10 transconjugants and caused the curing of a $300 \mathrm{kbp}$ plasmid, the same one that was lost upon the introduction of pKRE-1 (carrying the pSym replicator region) but perhaps different from that which was lost with plasmid $\mathrm{c}$ transfer, according to their relative positions in Eckhardt gels. Transconjugants bearing symbiotic plasmids from both CFN42 and Mim1 were tested for nodulation in Leucaena and bean and they formed similar numbers of nodules as the original strains. Fifteen isolates from the nodules formed by Miml transconjugants with two symbiotic plasmids were kanamycin resistant (marker for the R. etli CFN42 symbiotic plasmid) and Eckhardt plasmid profiles showed that both symbiotic plasmids were maintained in these nodule isolates. Plasmid $\mathrm{f}$ was not maintained in Mim 1, in comparison with transconjugants containing any of the other plasmids. Several kanamycin-resistant colonies obtained after the conjugal transfer of CFN42 plasmid $f$ $(630 \mathrm{kbp})$ did not have a plasmid corresponding to this size and Tn $5-m o b$ was shown by hybridization to be located on the megaplasmid in Mim1 recipients.

\section{DISCUSSION}

On the basis of current taxonomy for root-nodule bacteria (Graham et al., 1991), greater than $70 \%$ DNA-DNA homology, as well as distinctive phenotypic characters, is one of the main criteria for defining species, although in some cases strains sharing lower homology $(40-60 \%)$ have been found within a single species, as in the cases of $R$. tropici types $\mathrm{A}$ and $\mathrm{B}$ (Martínez-Romero et al., 1991) and Mesorhizobium plurifarium (de Lajudie et al., 1998a). The SSU rRNA gene sequence identity is used mainly as a criterion to estimate the generic position of bacteria, and strains within some species, such as $M$. loti, can have divergent SSU rRNA genes (de Lajudie et al., 1998a). In this study, identical PCR-RFLP patterns of SSU rRNA genes were found among the 50 isolates from $M$. affinis in Huautla and the type strain of $R$. etli in individual digestions with four restriction enzymes. This result indicated a close phylogenetic relationship between the isolates and the type strain of R. etli, since around $99 \%$ sequence identities were obtained between the SSU
rRNA genes that shared identical PCR-RFLP patterns digested with the same four enzymes in our previous reports (Wang et al., 1998, 1999a). This relationship between RFLP and sequence data was confirmed by a computer-simulated RFLP analysis of SSU rRNA genes (Moyer et al., 1996). To describe the specific status of the isolates, we characterized them further by genetic and phenotypic approaches. We concluded that the new isolates from Huautla were members of the species $R$. etli, on the basis of their close relationships and linkage equilibrium in MLEE analysis, high DNA-DNA homology (73-99\%), similar DNA fingerprints and several common phenotypic features (growth rate, colony morphology and resistance to nalidixic acid) to the reference strain of the species. Multiple nifH genes are a common characteristic of $R$. etli and $R$. leguminosarum (Martínez et al., 1985; Quinto et al., 1982; Segovia et al., 1993; Sessitsch et al., 1997) and they were also found in the isolates from $M$. affinis (Fig. 3). We did not include strain F16, the single $R$. etli strain reported to nodulate both bean and Leucaena plants (Hernández-Lucas et al., 1995), since further analysis of the strain used in that study showed us that it did not correspond to $R$. etli (data not shown).

The limited genetic diversity $(\mathrm{H}=0 \cdot 2)$ of the isolates from $M$. affinis revealed by MLEE analysis might be related to the small sampling size (11 plants) and the restricted sampling site. However, far larger genetic diversity was observed among $R$. etli bv. phaseoli strains $(H=0.6)$ obtained from a more restricted geographical area (Caballero-Mellado \& MartínezRomero, 1999). The large diversity of $R$. etli bv. phaseoli strains is striking (Piñero et al., 1988) and the species limits of $R$. etli have been difficult to define (Eardly et al., 1995). This may result from the population of $R$. etli harbouring the bv. phaseoli plasmid enlarging and diversifying more than that of bv. mimosae.

Generally, an MLEE group at a genetic distance of less than 0.5 shares more than $70 \%$ DNA homology (Caballero-Mellado \& Martínez-Romero, 1999; Martínez-Romero et al., 1991; Segovia et al., 1993; Wang et al., 1999a). This is also the case in this study (Fig. 1). The DNA homology data were also generally related to the genetic distances obtained when the ETs within an MLEE group were compared (Fig. 1). Mim2 had homology of $95 \%$ with F8, $100 \%$ with Mim3-7, $93 \%$ with Mim $1,80 \%$ with CFN42 and $74 \%$ with Viking1 in DNA-DNA hybridization. The genetic distances between Mim2 and these five isolates or strains increased gradually from $0 \cdot 1$ for $F 8$ to 0.3 for Viking1 in MLEE analysis. CFN42 had very similar genetic distances $(0 \cdot 20-0 \cdot 23)$ to the isolates in ETs $1-5$ in MLEE analysis and the DNA homology values were also quite similar (73-99\%).

The metabolic enzymes tested in this study were found to be chromosomally encoded in $R$. etli strain CFN42, since strains cured of each of the plasmids presented 
bands identical to the wild-type strain (S. Brom \& J. Caballero-Mellado, personal communication). We observed conserved plasmid patterns in isolates within some ETs, such as ET 4 and ET 5. Although a common plasmid (the symbiotic plasmid) was found, different plasmid patterns were obtained among different ETs and among the 17 isolates within ET 2, the ET with the largest number of isolates, showing that plasmids constitute the most diverse components in these populations.

Even though extensive screenings of Mesoamerican legumes have been performed, we had previously isolated $R$. etli mainly from Phaseolus bean nodules and not from any wild legumes (Martínez et al., 1985; Wang et al., 1998, 1999b; Barrera et al., 1997). It is remarkable that the new $R$. etli host plant is a member of the subfamily Mimosoideae that has not been cultivated and comes from an undisturbed area. Wild Phaseolus species have also been reported to occur in Huautla (O. Dorado, personal communication); thus, both hosts share a geographical distribution area, which may have facilitated their sharing of symbionts. We show here that, although very similar at the chromosomal level, isolates from $P$. vulgaris and $M$. affinis have differences attributable to diverging plasmids, especially the symbiotic plasmids.

The best characterized of all plasmids in Rhizobium are the symbiotic plasmids and, consequently, our comparison of isolates from Phaseolus and Mimosa is most complete for these plasmids. Differential nodulation specificity was found among isolates from $M$. affinis and $P$. vulgaris. Isolates from both $P$. vulgaris and $M$. affinis could nodulate $P$. vulgaris, but only the isolates from $M$. affinis could nodulate $L$. leucocephala. Different sizes of symbiotic plasmids were recorded among the isolates or strains from these two host plants (Table 1). The hybridization patterns for nif $H$, which had been located on the symbiotic plasmids, observed for the isolates from $M$. affinis (Fig. 3) were not similar to any of the nifH patterns reported in strains from $P$. vulgaris (Martínez et al., 1985; PérezRamírez et al., 1998; Sessitsch et al., 1997), indicating a different genetic organization of the symbiotic plasmid of the isolates from $M$. affinis from that of strains from $P$. vulgaris. No homology to the replicator sequence CFN42 pSym was observed by hybridization and by mating tests on the plasmids in the isolates from M. affinis. Melanin production, a typical feature of most $R$. etli strains from $P$. vulgaris (MartínezRomero, 1996; Michiels et al., 1994), is symbioticplasmid-encoded and none of the isolates from $M$. affinis produced it. We concluded that the symbiotic plasmids were different in the isolates from $P$. vulgaris and $M$. affinis.

All R. etli bv. phaseoli strains have symbiotic plasmids with homology to the CFN42 pSym replicator region (Ramírez-Romero et al., 1997), which was not the case in the isolates in $R$. etli bv. mimosae. In nature, strains could exist with both symbiotic plasmids found in the isolates from $P$. vulgaris and $M$. affinis, since these symbiotic plasmids belong to different compatibility groups (see Results) and have different replicator regions. Under laboratory conditions, Mim1 transconjugants carrying an additional symbiotic plasmid from CFN42 were stable, even after passage through bean nodules. Nevertheless, strains with two symbiotic plasmids may be less competitive for nodule formation and, as such, are not normally recovered from nodules.

The nif $H$ gene-based phylogram we obtained is similar to that reported previously (Haukka et al., 1998). Two different $R$. etli bv. phaseoli strains, CFN42 and Olivia 4 , were found to have identical nifH sequences (accession numbers M15941 and M55227, respectively). The similarity of the nif $H$ genes among bv. phaseoli and bv. mimosae plasmids suggests that they evolved from a common ancestor. It is remarkable that rhizobia that can nodulate Leucaena as well as bean, such as $R$. etli bv. mimosae (described here) and $R$. gallicum bv. gallicum FL27 (Eardly et al., 1992), have nif $H$ genes sharing the same ancestry as those of $R$. etli bv. phaseoli (Fig. 4). It seems that R. etli bv. phaseoli lost the capacity to nodulate Leucaena and became more specialized for bean. The evolution of $R$. etli bv. phaseoli from a generalist to a specialist might have been driven by the extensive cultivation of bean. Similarly, it seems that the $R$. fredii symbiotic plasmid (such as that from USDA257) evolved from a more promiscuous plasmid, as both NGR234 and USDA257 symbiotic plasmids are very similar (Krishnan et al., 1992; X. Perret and W. J. Broughton, personal communication). Interestingly, USDA257, like R. etli bv. phaseoli, no longer nodulates Leucaena, and the genetic differences from NGR234 involved in this change of specificity have been analysed (Krishnan et al., 1992). It has been assumed that coevolution has occurred in the Rhizobium-legume interaction, mainly related to symbiotic-plasmid-borne genes (Ueda et al., 1995). Our data support this hypothesis, since both $R$. etli bv. mimosae and bv. phaseoli share the same gene pool, as revealed by MLEE analysis and DNA-DNA hybridization, but the symbiotic plasmids are different.

In $R$. etli bv. phaseoli, plasmids other than the pSym play a role in symbiosis (Brom et al., 1992), for example CFN42 plasmid $\mathrm{f}$ has reiterated copies of fixNOQP, fixGHI and fixK and an unusual fixL gene, and bacteria cured of this plasmid are less efficient in nitrogen fixation (Girard et al., 1998). Plasmids such as plasmids $\mathrm{c}$, e and $\mathrm{f}$ from CFN42 seem to be conserved in isolates from both Mimosa and Phaseolus. The high DNA-DNA homology encountered among the isolates from Mimosa and Phaseolus is also indicative of chromosomal as well as of plasmid homology, as discussed previously for the interpretation of DNADNA homology values in rhizobia (MartínezRomero, 1994). It was thus of interest to test the $I p s \beta$ genes as markers for plasmid $\mathrm{b}$ of $R$. etli CFN42. CFN42 plasmid $b$ has also been assigned a role in the symbiosis with bean (Brom et al., 1992) and is highly conserved among different $R$. etli and $R$. legum- 
inosarum strains (García-de los Santos \& Brom, 1997). The lps $\beta$ genes are also conserved in isolates from Mimosa, although on a different replicon in some of them.

Scarce nodulation was obtained on $M$. affinis roots when plants were grown in Cuernavaca soil, and the two isolates were not $R$. etli, although $M$. affinis is also native to Cuernavaca $(\mathrm{O}$. Dorado, personal communication). We found a similar situation with $R$. huautlense, a bacterium nodulating Sesbania herbacea, which was found only in Sierra de Huautla and not in Cuernavaca soils (Wang et al., 1998). This probably indicates that Huautla, perhaps because of its geographical isolation, is a unique source of bacterial and plant diversity.

Tropical forests have a large diversity of plant species and also highly diverse microbial populations. Tropical plants may be hosts for new Rhizobium species, but this is not always the case. It was surprising that strains isolated from taxonomically distant host plants in previously unexplored environments corresponded to strains already described, largely from agricultural systems (Moreira et al., 1998). Similarly, we did not recover a new rhizobial lineage from $M$. affinis, but rather a well-known species differing in its type of symbiotic plasmid and apparently also in other plasmids.

Common Rhizobium genetic backgrounds may harbour symbiotic plasmids with different specificities. The biovar designation in Rhizobium species is meant to refer to the symbiotic plasmids within a single type of chromosome, for example bv. viciae, bv. trifolii and bv. phaseoli within $R$. leguminosarum (Jordan, 1984) and bv. sesbaniae and bv. acaciae within $S$. terangae (Boivin et al., 1997). When the species $R$. etli was described (Segovia et al., 1993), the existence of biovars, bv. phaseoli and bv. viciae, within this species was discussed. Due to the small number of bv. viciae isolates analysed, the Subcommittee on the taxonomy of Rhizobium and Agrobacterium approved the species but deferred assignment of $R$. etli biovars for the time being (Martínez-Romero \& Jarvis, 1993).

On the basis of our results, we propose a novel biovar within the species $R$. etli, bv. mimosae, for the isolates from $M$. affinis obtained in Huautla. The nodulation on L. leucocephala and non-production of melanin could be phenotypic features to distinguish the new biovar from the previously reported biovar, bv. phaseoli (Segovia et al., 1993). The sizes, replicator regions and nifH gene organizations of the symbiotic plasmids and nif $H$ gene sequences illustrate the genetic differences between these two biovars. Furthermore, there seems to exist a 'null' biovar of rhizobium lacking symbiotic plasmids. Non-symbiotic $R$. etli strains were recovered from the bean rhizosphere more frequently than symbiotic ones (Segovia et al., 1991). The natural occurrence of these rhizobia, lacking plasmids but genetically intermingled with symbiotic bacteria, suggests that the former may be receptors in plasmid transfers at a frequency to prevent the nonsymbiotic lineage from diverging from the symbiotic ones, a somewhat similar situation to that of genetic lateral transfer occurring in $M$. loti (Sullivan et al., 1995).

\section{ACKNOWLEDGEMENTS}

We thank Dr Michael Dunn for critically reading the manuscript and Dr Oscar Dorado for offering the Mimosa affinis plants and seeds. Partial financial support was from grant IN202097 from DGAPA UNAM, México.

\section{REFERENCES}

Amarger, N., Macheret, V. \& Laguerre, G. (1997). Rhizobium gallicum sp. nov. and Rhizobium giardinii sp. nov., from Phaseolus vulgaris nodules. Int J Syst Bacteriol 47, 996-1006.

Barrera, L. L., Trujillo, M. E., Goodfellow, M., García, F. J., Hernández-Lucas, I., Dávila, G., van Berkum, P. \& MartínezRomero, E. (1997). Biodiversity of bradyrhizobia nodulating Lupinus spp. Int J Syst Bacteriol 47, 1086-1091.

van Berkum, P., Beyene, D. \& Eardly, B. D. (1996). Phylogenetic relationships among Rhizobium species nodulating the common bean (Phaseolus vulgaris L.). Int J Syst Bacteriol 46, 240-244.

van Berkum, P., Beyene, D., Bao, G., Campbell, T. A. \& Eardly, B. D. (1998). Rhizobium mongolense sp. nov. is one of three rhizobial genotypes identified which nodulate and form nitrogenfixing symbioses with Medicago ruthenica [(L.) Ledebour]. Int J Syst Bacteriol 48, 13-22.

Boivin, C., Ndoye, I., Lortet, G., Ndiaye, A., de Lajudie, P. \& Dreyfus, B. (1997). The Sesbania root symbionts Sinorhizobium saheli and $S$. teranga bv. sesbaniae can form stem nodules on Sesbania rostrata although they are less adapted to stem nodulation than Azorhizobium caulinodans. Appl Environ Microbiol 63, 1040-1047.

Brom, S., García-de los Santos, A., Stepkowsky, T., Flores, M., Dávila, G., Romero, D. \& Palacios, R. (1992). Different plasmids of Rhizobium leguminosarum bv. phaseoli are required for optimal symbiotic performance. $J$ Bacteriol 174, 5183-5189.

Caballero-Mellado, J. \& Martínez-Romero, E. (1994). Limited genetic diversity in the endophytic sugarcane bacterium Acetobacter diazotrophicus. Appl Environ Microbiol 60, 1532-1537.

Caballero-Mellado, J. \& Martínez-Romero, E. (1999). Soil fertilization limits the genetic diversity of Rhizobium in bean nodules. Symbiosis 26, 111-121.

Campelo, A. B. \& Dobereiner, J. (1969). Estudo sobre inoculaçao cruzada de algumas leguminosas florestais. Pesqui Agropecu Bras 4, 67-72.

Chen, W. X., Li, G. S., Qi, Y. L., Wang, E. T., Yuan, H. L. \& Li, J. L. (1991). Rhizobium huakuii sp. nov. isolated from the root nodules of Astragalus sinicus. Int J Syst Bacteriol 41, 275-280.

Chen, W. X., Wang, E. T., Wang, S. Y., Li, Y. B., Chen, X. Q. \& Li, Y. (1995). Characteristics of Rhizobium tianshanense sp. nov., a moderately and slowly growing root nodule bacterium isolated from an arid saline environment in Xinjiang, People's Republic of China. Int J Syst Bacteriol 45, 153-159.

Chen, W.-X., Tan, Z.-Y., Gao, J.-L., Li, Y. \& Wang, E.-T. (1997). Rhizobium hainanense sp. nov., isolated from tropical legumes. Int J Syst Bacteriol 47, 870-873.

Dénarié, J., Debellé, F. \& Promé, J.-C. (1996). Rhizobium lipochitooligosaccharide nodulation factors: signaling molecules 
mediating recognition and morphogenesis. Annu Rev Biochem 65, 503-535.

Ditta, G., Stanfield, S., Corbin, D. \& Helinski, D. R. (1980). Broad host range DNA cloning system for gram-negative bacteria: construction of a gene bank of Rhizobium meliloti. Proc Natl Acad Sci USA 77, 7347-7351.

Doyle, J. J. (1995). DNA data and legume phylogeny: a progress report. In Advances in Legume Systematics 7: Phylogeny, pp. 11-30. Edited by M. Crisp \& J. J. Doyle. Kew: Royal Botanic Gardens.

Dreyfus, B., Garcia, J. L. \& Gillis, M. (1988). Characterization of Azorhizobium caulinodans gen. nov., sp. nov., a stem-nodulating nitrogen-fixing bacterium isolated from Sesbania rostrata. Int $J$ Syst Bacteriol 38, 89-98.

Dupuy, N., Willems, A., Pot, B. \& 7 other authors (1994). Phenotypic and genotypic characterization of bradyrhizobia nodulating the leguminous tree Acacia albida. Int $J$ Syst Bacteriol 44, 461-473.

Eardly, B. D., Young, J. P. W. \& Selander, R. K. (1992). Phylogenetic position of Rhizobium sp. strain Or 191, a symbiont of both Medicago sativa and Phaseolus vulgaris, based on partial sequences of the 16S rRNA and nifH genes. Appl Environ Microbiol 58, 1809-1815.

Eardly, B. D., Wang, F.-S., Whittam, T. S. \& Selander, R. K. (1995). Species limits in Rhizobium populations that nodulate the common bean (Phaseolus vulgaris). Appl Environ Microbiol 61, 507-512.

Fåhraeus, G. (1957). The infection of clover root hairs by nodule bacteria studied by a simple glass slide technique. $J$ Gen Microbiol 16, 374-381.

Freiberg, C., Fellay, R., Bairoch, A., Broughton, W. J., Rosenthal, A. \& Perret, X. (1997). Molecular basis of symbiosis between Rhizobium and legumes. Nature 387, 394-401.

García-de los Santos, A. \& Brom, S. (1997). Characterization of two plasmid-borne lps $\beta$ loci of Rhizobium etli required for lipopolysaccharide synthesis and for optimal interaction with plants. Mol Plant-Microbe Interact 7, 891-902.

Genetics Computer Group (1995). Program Manual for the Wisconsin Package, Version 8. Genetics Computer Group, Madison, 53711 WI, USA.

Geniaux, E., Laguerre, G. \& Amarger, N. (1993). Comparison of geographically distant populations of Rhizobium isolated from root nodules of Phaseolus vulgaris. Mol Ecol 2, 295-302.

Geniaux, E., Flores, M., Palacios, R. \& Martinez, E. (1995). Presence of megaplasmids in Rhizobium tropici and further evidence of differences between the two $R$. tropici subtypes. Int $J$ Syst Bacteriol 45, 392-394.

Girard, L., Brom, S. \& Romero, D. (1998). Characterization of reiterated fix genes in Rhizobium etli CFN42. In 16th North American Conference on Symbiotic Nitrogen Fixation. V.09. February 1-6. Cancún, México.

Graham, P. H., Sadowsky, M. J., Keyser, H. H. \& 8 other authors (1991). Proposed minimal standards for the description of new genera and species of root- and stem-nodulating bacteria. Int $J$ Syst Bacteriol 41, 582-587.

Haukka, K., Lindström, K. \& Young, J.P. W. (1998). Three phylogenetic groups of nodA and nifH genes in Sinorhizobium and Mesorhizobium isolates from leguminous trees growing in Africa and Latin America. Appl Environ Microbiol 64, 419-426. Hernández-Lucas, I., Segovia, L., Martínez-Romero, E. \& Pueppke, S. G. (1995). Phylogenetic relationships and host range of
Rhizobium spp. that nodulate Phaseolus vulgaris L. Appl Environ Microbiol 61, 2775-2779.

Hynes, M. F. \& McGregor, N. F. (1990). Two plasmids other than the nodulation plasmid are necessary for formation of nitrogenfixing nodules by Rhizobium leguminosarum. Mol Microbiol 4, 567-574.

Jarvis, B. D. W., van Berkum, P., Chen, W. X., Nour, S. M., Fernandez, M. P., Cleyet-Marel, J.-C. \& Gillis, M. (1997). Transfer of Rhizobium loti, Rhizobium huakuii, Rhizobium ciceri, Rhizobium mediterraneum, and Rhizobium tianshanense to Mesorhizobium gen. nov. Int $J$ Syst Bacteriol 47, 895-898.

Jordan, D. C. (1984). Family III. Rhizobiaceae Conn 1938, $321^{\mathrm{AL}}$. In Bergey's Manual of Systematic Bacteriology, vol. 1, pp. 234-254. Edited by N. R. Krieg \& J. G. Holt. Baltimore: Williams \& Wilkins.

Krishnan, H. B., Lewin, A., Fellay, R., Broughton, W. J. \& Pueppke, S. G. (1992). Differential expression of nodS accounts for the varied abilities of Rhizobium fredii USDA257 and Rhizobium sp. strain NGR234 to nodulate Leucaena spp. Mol Microbiol 6, 3321-3330.

Laguerre, G., Fernandez, M. P., Edel, V., Normand, P. \& Amarger, N. (1993). Genomic heterogeneity among French Rhizobium strains isolated from Phaseolus vulgaris L. Int $J$ Syst Bacteriol 43, 761-767.

Laguerre, G., Allard, M.-R., Revoy, F. \& Amarger, N. (1994). Rapid identification of rhizobia by restriction fragment length polymorphism analysis of PCR-amplified 16S rRNA genes. Appl Environ Microbiol 60, 56-63.

Laguerre, G., Mavingui, P., Allard, M.-R., Charnay, M. P., Louvrier, P., Mazurier, S. I., Rigottier-Gois, L. \& Amarger, N. (1996). Typing of rhizobia by PCR DNA fingerprinting and PCR-restriction fragment length polymorphism analysis of chromosomal and symbiotic gene regions: application to Rhizobium leguminosarum and its different biovars. Appl Environ Microbiol 62, 2029-2036.

de Lajudie, P., Willems, A., Pot, B. \& 7 other authors (1994). Polyphasic taxonomy of rhizobia: emendation of the genus Sinorhizobium and description of Sinorhizobium meliloti comb. nov., Sinorhizobium saheli sp. nov., and Sinorhizobium teranga sp. nov. Int $J$ Syst Bacteriol 44, 715-733.

de Lajudie, P., Willems, A., Nick, G. \& 9 other authors (1998a). Characterization of tropical tree rhizobia and description of Mesorhizobium plurifarium sp. nov. Int $J$ Syst Bacteriol 48, 369-382.

de Lajudie, P., Laurent-Fulele, E., Willems, A., Torck, U., Coopman, R., Collins, M. D., Kersters, K., Dreyfus, B. \& Gillis, M. (1998b). Allorhizobium undicola gen. nov., sp. nov., nitrogen-fixing bacteria that efficiently nodulate Neptunia natans in Senegal. Int $J$ Syst Bacteriol 48, 1277-1290.

Lindström, K. (1989). Rhizobium galegae, a new species of legume root nodule bacteria. Int J Syst Bacteriol 39, 365-367.

Martínez, E., Pardo, M. A., Palacios, R. \& Cevallos, M. A. (1985). Reiteration of nitrogen fixation gene sequences and specificity of Rhizobium in nodulation and nitrogen fixation in Phaseolus vulgaris. J Gen Microbiol 131, 1779-1786.

Martínez, E., Palacios, R. \& Sánchez, F. (1987). Nitrogen-fixing nodules induced by Agrobacterium tumefaciens harboring Rhizobium phaseoli plasmids. J Bacteriol 169, 2828-2834.

Martínez, E., Romero, D. \& Palacios, R. (1990). The Rhizobium genome. Crit Rev Plant Sci 9, 59-93.

Martínez-Romero, E. (1994). Recent developments in Rhizobium taxonomy. Plant Soil 161, 11-20. 
Martínez-Romero, E. (1996). Comments on Rhizobium systematics. Lessons from $R$. tropici and $R$. etli. In Biology of Plant-Microbe Interactions, pp. 503-508. Edited by G. Stacey, B. Mullin \& P. M. Gresshoff. St Paul, MN: International Society for Plant-Microbe Interactions.

Martínez-Romero, E. \& Caballero-Mellado, J. (1996). Rhizobium phylogenies and bacterial genetic diversity. Crit Rev Plant Sci 15, 113-140.

Martínez-Romero, E. \& Jarvis, B. D. W. (1993). International Committee on Systematic Bacteriology, Subcommittee on the Taxonomy of Agrobacterium and Rhizobium, Minutes of the Meeting. Int J Syst Bacteriol 43, 622.

Martínez-Romero, E., Segovia, L., Mercante, F. M., Franco, A. A., Graham, P. \& Pardo, M. A. (1991). Rhizobium tropici, a novel species nodulating Phaseolus vulgaris L. beans and Leucaena sp. trees. Int J Syst Bacteriol 41, 417-426.

Michiels, J., D'hooghe, I., Verreth, C., Pelemans, H. \& Vanderleyden, J. (1994). Characterization of the Rhizobium leguminosarum biovar phaseoli nif $A$ gene, a positive regulator of nif gene expression. Arch Microbiol 161, 404408.

Moreira, F. M. S., Haukka, K. \& Young, J. P. W. (1998). Biodiversity of rhizobia isolated from a wide range of forest legumes in Brazil. Mol Ecol 7, 889-895.

Morett, E., Moreno, S. \& Espin, G. (1988). Transcription analysis of the three nifH genes of Rhizobium phaseoli with gene fusions. Mol Gen Genet 213, 499-504.

Moyer, C. L., Tiedje, J. M., Dobbs, F. C. \& Karl, D. M. (1996). A computer-simulated restriction fragment length polymorphism analysis of bacterial small-subunit rRNA genes: efficacy of selected tetrameric restriction enzymes for studies of microbial diversity in nature. Appl Environ Microbiol 62, 2501-2507.

Nei, M. \& Li, W. H. (1979). Mathematical model for studying genetic variation in terms of restriction endonucleases. Proc Natl Acad Sci USA 76, 5269-5273.

Nour, S. M., Fernandez, M. P., Normand, P. \& Cleyet-Marel, J.-C. (1994). Rhizobium ciceri sp. nov., consisting of strains that nodulate chickpeas (Cicer arietinum L.). Int J Syst Bacteriol 44, 511-522.

Nour, S. M., Cleyet-Marel, J.-C., Normand, P. \& Fernandez, M. P. (1995). Genomic heterogeneity of strains nodulating chickpeas (Cicer arietinum L.) and description of Rhizobium mediterraneum sp. nov. Int J Syst Bacteriol 45, 640-648.

Novikova, N. I. \& Safronova, V. (1992). Transconjugants of Agrobacterium radiobacter harbouring sym genes of $R$. galegae can form an effective symbiosis with Medicago sativa. FEMS Microbiol Lett 93, 262-268.

Oyaizu, H., Matsumoto, S., Minamisawa, K. \& Gamou, T. (1993). Distribution of rhizobia in leguminous plants surveyed by phylogenetic identification. J Gen Appl Microbiol 39, 339-354.

Pérez-Ramírez, N. O., Rogel, M. A., Wang, E. T., Castellanos, J. Z. \& Martínez-Romero, E. (1998). Seeds of Phaseolus vulgaris carry Rhizobium etli. FEMS Microbiol Ecol 26, 289-296.

Piñero, D., Martínez, E. \& Selander, R. K. (1988). Genetic diversity and relationships among isolates of Rhizobium leguminosarum biovar phaseoli. Appl Environ Microbiol 54, 2825-2832.

Quinto, C., de la Vega, H., Flores, M., Fernández, L., Ballado, T., Soberón, G. \& Palacios, R. (1982). Reiteration of nitrogen fixation gene sequences in Rhizobium phaseoli. Nature 299, 724-726.

Ramírez-Romero, M. A., Bustos, P., Girard, L., Rodríguez, O., Cevallos, M. A. \& Dávila, G. (1997). Sequence, localization and characteristics of the replicator region of the symbiotic plasmid of Rhizobium etli. Microbiology 143, 2825-2831.

Raven, P. H. \& Polhill, R. M. (1981). Biogeography of the Leguminosae. In Advances in Legume Systematics VI, pp. 27-34. Edited by R. M. Polhill \& P. H. Raven. Kew: Royal Botanic Gardens.

Relic, B., Perret, X., Estrada-García, M. T., Kopcinska, J., Golinowski, W., Krishnan, H. B., Pueppke, S. G. \& Broughton, W. J. (1994). Nod factors of Rhizobium are a key to the legume door. Mol Microbiol 13, 171-178.

Rhoads, D. D. \& Roufa, D. J. (1989). SEQAID II (tm) version 3.5. Molecular Genetics Laboratory, Kansas State University, KS, USA.

Romero, D., Brom, S., Martínez-Salazar, J., de Lourdes Girard, M., Palacios, R. \& Dávila, G. (1991). Amplification and deletion of a nod-nif region in the symbiotic plasmid of Rhizobium phaseoli. $J$ Bacteriol 173, 2435-2441.

Sambrook, J., Fritsch, E. F. \& Maniatis, T. (1989). Molecular Cloning : a Laboratory Manual, 2nd edn. Cold Spring Harbor, NY : Cold Spring Harbor Laboratory.

Segovia, L., Piñero, D., Palacios, R. \& Martínez-Romero, E. (1991). Genetic structure of a soil population of nonsymbiotic Rhizobium leguminosarum. Appl Environ Microbiol 57, 426-433.

Segovia, L., Young, J.P. W. \& Martínez-Romero, E. (1993). Reclassification of American Rhizobium leguminosarum biovar phaseoli type I strains as Rhizobium etli sp. nov. Int $J$ Syst Bacteriol 43, 374-377.

Selander, R. K., Caugant, D. A., Ochman, H., Musser, J. M., Gilmour, M. N. \& Whittam, T. S. (1986). Methods of multilocus enzyme electrophoresis for bacterial population genetics and systematics. Appl Environ Microbiol 51, 873-884.

Sessitsch, A., Hardarson, G., Akkermans, A. D. L. \& De Vos, W. M. (1997). Characterization of Rhizobium etli and other Rhizobium spp. that nodulate Phaseolus vulgaris L. in an Austrian soil. Mol Ecol 6, 601-608.

Souza, V. \& Eguiarte, L. E. (1997). Bacteria gone native vs. bacteria gone awry?: plasmidic transfer and bacterial evolution. Proc Natl Acad Sci USA 94, 5501-5503.

Souza, V., Nguyen, T. T., Hudson, R. R., Piñero, D. \& Lenski, R. E. (1992). Hierarchical analysis of linkage disequilibrium in $R h i-$ zobium populations: evidence for sex? Proc Natl Acad Sci USA 89, 8389-8393.

Stanley, J., Dowling, D. N., Stucker, M. \& Broughton, W. J. (1987). Screening costramid libraries for chromosomal genes: an alternative interspecific hybridization method. FEMS Microbiol Lett 48, 25-30.

Sullivan, J. T., Patrick, H. N., Lowther, W. L., Scott, D. B. \& Ronson, C. W. (1995). Nodulating strains of Rhizobium loti arise through chromosomal symbiotic gene transfer in the environment. Proc Natl Acad Sci USA 92, 8985-8989.

Tan, Z.-Y., Xu, X.-D., Wang, E.-T., Gao, J.-L., Martínez-Romero, E. \& Chen, W.-X. (1997). Phylogenetic and genetic relationships of Mesorhizobium tianshanense and related rhizobia. Int J Syst Bacteriol 47, 874-879.

Thompson, J. D., Higgins, D. G. \& Gibson, T. J. (1994). CLUSTAL $\mathbf{W}$ : improving the sensitivity of progressive multiple sequence alignment through sequence weighting, position-specific gap penalties and weight matrix choice. Nucleic Acids Res 22, 4673-4680.

Trinick, M. J. (1980). Relationships among the fast-growing rhizobia of Lablab purpureus, Leucaena leucocephala, Mimosa 
spp., Acacia farnesiana and Sesbania grandiflora and their affinities with other Rhizobium groups. $J$ Appl Bacteriol 49, $39-53$.

Ueda, T., Suga, Y., Yahiro, N. \& Matsuguchi, T. (1995). Phylogeny of Sym plasmids of rhizobia by PCR-based sequencing of a nodC segment. J Bacteriol 177, 468-472.

Vincent, J. M. (1970). A Manual for the Practical Study of the Root Nodule Bacteria. International Biological Programme IBP Handbook 15. Oxford: Blackwell.

Wang, E. T., van Berkum, P., Beyene, D., Sui, X. H., Dorado, O., Chen, W. X. \& Martínez-Romero, E. (1998). Rhizobium huautlense sp. nov., a symbiont of Sesbania herbacea that has a close phylogenetic relationship with Rhizobium galegae. Int J Syst Bacteriol 48, 687-699.

Wang, E. T., van Berkum, P., Sui, X. H., Beyene, D., Chen, W. X. \&
Martínez-Romero, E. (1999a). Diversity of rhizobia associated with Amorpha fruticosa isolated from Chinese soils and description of Mesorhizobium amorphae sp. nov. Int J Syst Bacteriol 49, 51-65.

Wang, E. T., Martínez-Romero, J. \& Martínez-Romero, E. (1999b). Genetic diversity of rhizobia nodulating Leucaena leucocephala in Mexican soils. Mol Ecol 8, 711-724.

Weisburg, W. G., Barns, S. M., Pelletier, D. A. \& Lane, D. J. (1991). $16 \mathrm{~S}$ ribosomal DNA amplification for phylogenetic study. $J$ Bacteriol 173, 697-703.

Young, J. P. W. (1985). Rhizobium population genetics: enzyme polymorphism in isolates from peas, clover, beans and lucerne grown at the same site. J Gen Microbiol 131, 2399-2408.

Young, J. P. W. \& Haukka, K. E. (1996). Diversity and phylogeny of rhizobia. New Phytol 133, 87-94. 